\title{
ПСИХИЧКА ОПТОВАРЕНОСТ, ДЕПРЕСИВНОСТ, СОЦИЈАЛНА ПОДДРШКА И СПРАВУВАҢЕ КАКО ПРЕДИКТОРИ НА КВАЛИТЕТОТ НА ЖИВОТ КАЈ НЕФОРМАЛНИ НЕГУВАТЕЛИ НА ЛИЦА СО ДЕМЕНЦИЈА
}

\section{Марија Танеска ${ }^{1}$}

\section{Кратка содржина}

Целта на ова истражување е да се утврди дали психичката оптовареност, депресивноста, социјалната поддршка и пристапувачкиот стил на справување се значајни предиктори на квалитетот на живот кај неформалните негуватели на лица со деменција. Истражувањето е спроведено на меѓународен примерок кој го сочинуваа 106 испитаници од кои 30 беа од Република Северна Македонија. За целите на истражувањето беа користени Прашалникот за квалитет на живот на негуватели на лица со деменција, Интервјуто за оптовареност на Зарит, Прашалникот за здравствена состојба на пациенти, Краткиот прашалник за пристапување/избегнување, Кратката скала за перципирана поддршка и прашалници за когнитивниот статус и однесувањето на лицата со деменција. Истражувањето е спроведено на интернет. Од добиените наоди од хиерархиската регресивна анализа може да се заклучи дека повисоката оптовареност, повисоката депресивност и пониската социјална поддршка предвидуваат полош квалитет на живот кај неформалните негуватели на лица со деменција. Ваквите наоди укажуваат на потребата за сеопфатна системска поддршка на неформалните негуватели на лица со деменција како би се намалиле изворите на нарушен квалитет на живот кај нив.

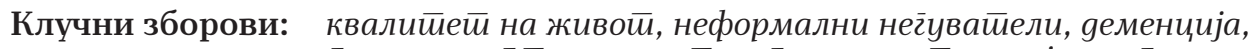

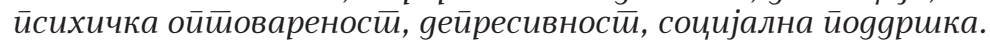

tmarija2408@gmail.com 
М. ТАНЕСКА: ПСИХИЧКА ОПТОВАРЕНОСТ, ДЕПРЕСИВНОСТ, СОЦИЈАЛНА ПОДДРШКА И СПРАВУВАњЕ...

\section{Вовед}

Деменција е заеднички термин за повеќе болести кои ги засегаат помнењето, другите когнитивни процеси и однесувањето, и значајно влијаат врз способноста на лицето да ги извршува секојдневните активности (World Health Organisation, 2017). Стапката на деменција значително расте секоја година, а моментално во светот има 50 милиони луѓе кои се заболени, од кои околу 40 \% се сместени во дом, а 60 \% се во своите семејства, при што грижата за нив паѓа на нивните најблиски, односно на неформалните негуватели (Alzheimer Society, 2007). Под неформален негувател се подразбира лице кое не е платено за грижата на роднина или пријател кој не може да функционира без нивната помош. Во Република Северна Македонија во 2019 година имало 20.000 лица заболени од деменција, а само 20 \% се дијагностицирани и лекувани (Новотни, 2019). Притоа, само 1.371 лице (со и без деменција) било сместено во дом за возрасни лица во 2017 година, според Државниот завод за статистика (2018) што значи дека и во РСМ најголем дел од лицата со деменција живеат во своите домови. Поради ефектите кои грижата за лице со деменција ги има врз неформалните негуватели тие често се нарекуваат и „невидливи пациенти“.

Грижата за лице со деменција може на разновидни начини да ги засегне сите аспекти на квалитетот на живот на луѓето кои се директно вклучени во неа, затоа што самиот процес се одразува врз нив преку нарушување на физичкото и психичкото здравје (Farina et al., 2017), незадоволување на потребите и намалена независност и лична слобода (Bangerter, Griffin, Zarit, Havyer, 2019). Во неодамнешен систематски преглед на истражувања во оваа област (Farina et al., 2017) издвоени се повеќе категории на фактори поврзани со квалитетот на живот на неформалните негуватели на лица со деменција. Заедничкото живеење со лицето со деменција, како демографска карактеристика, негативно е поврзано со квалитетот на живот. Од факторите кои произлегуваат од односот на негувателот со лицето со деменција значајни се видот на однос, при што сопружниците имаат полош квалитет на живот отколку децата во негувателска улога, како и малата емоционална блискост и перципираните промени во односот, кои исто така, негативно корелираат со квалитетот на живот. Карактеристиките на деменцијата кои се поврзани со полош квалитет на живот се: повисок степен на функционално нарушување, посилно изразени бихевиорални и психолошки симптоми и помала свесност за состојбата кај лицето со деменција. Фактори кои произлегуваат од здравјето и од емоционалната добросостојба на негувателите, а кои негативно корелираат со квалитетот на живот се: депресивноста, анксиозноста, нарушеното физичко здравје и влошениот квалитет на сонот. 
Барањата на негувателството поврзани со понизок квалитет на живот се: чувство на „согорување“, негувателски стрес и субјективна оптовареност наспроти објективните барања за кои не е утврдена силна поврзаност со квалитетот на живот. Ниското задоволство од социјалната поддршка, намалената независност и грижата за иднината, исто така, негативно корелираат со квалитетот на живот. Од друга страна, подобар квалитет на живот имаат негувателите кои наоѓаат задоволство и значење во грижата, кои имаат повисоки приходи, повисок степен на самоефикасност и вештини за справување.

Во повеќе истражувања, покрај тоа, е утврдена поврзаност помеѓу депресивноста и квалитетот на живот (Bruvik, Ulstein. Ranhoff, Engedal, 2012; Kong, Hu, Yao, Zhao, 2019; Moreno et al., 2015; Novelli \& Caramelli, 2010; Papastavrou et al., 2014; Santos et al., 2014). Според Takai и соработниците (2011) депресивноста е најсилен предиктор на квалитетот на живот кај негувателите на лицата со деменција. Депресивноста е поизразена кај жените (Haley, LaMonde, Han, Burton, \& Schonwetter, 2003; Schulz \& Williamson, 1991; Zanetti et al., 1998) кога негувателот е сопружник на лицето со деменција (Zanetti et al., 1998) и кога живеат заедно (Schulz \& Williamson, 1991). Негативните социјални интеракции, нискиот степен на социјална поддршка, незадоволството од социјалните контакти и социјалната мрежа како и нискиот број на посети од роднини и пријатели се поврзани со повисок степен на депресивност (Haley et al., 2003; Schulz \& Williamson, 1991). Степенот на когнитивно нарушување, интензитетот и бројот на проблематични однесувања, стадиумот на болеста и возраста на лицето со деменција се, исто така, поврзани со депресивноста кај негувателите (Haley et al., 2003; Schulz \& Williamson, 1991; Yates, Tennstedt, \& Chang, 2009; Zanetti et al., 1998). Подепресивни се негувателите кои се чувствуваат осамени (Beeson, 2003), а депресивноста кај негувателите е поврзана и со депресивноста кај лицето за кое се грижат (Teri, 1997).

Психичката оптовареност, исто така, во голем број истражувања се јавува како предиктор на квалитетот на живот на негувателите на лица со деменција (Bruvik et al., 2012; Keniş-Coşkun et al., 2019; Markowitz, Gutterman, Sadik, Papadopolous, 2003; Nogueira et al., 2015; Novelli \& Caramelli, 2010; Papastavrou et al., 2014; Santos et al., 2014). Таа се дефинира како „степен до кој емоционалното и физичкото здравје на негувателот, неговиот/нејзиниот социјален живот и финансиски статус страдаат како резултат на грижата за друго лице“ (Zarit, Reever, BachPeterson, 1980; Zarit, Tod \& Zarit, 1986) или „мултидимензионален одговор на физичките, емоционалните, социјалните и финансиските стресори поврзани со негувателското искуство“ (Kasuya, Polgar-Bailey, \& Takeuchi, 2000 според Etters, Goodall, \& Harrison, 2008). Два аспекти на оптовареноста се: објективна 
оптовареност (опиплив, видлив влог на негувателот како: време поминато во грижа или време изгубено од работа поради негувателските обврски) и субјективна оптовареност (субјективна оценка на негувателската улога, степен до кој влијае или ја оневозможува негувателската улога и емоционалната реакција на објективната оптовареност) (Hughes et al., 2014). McConaghy и Caltabiano (2005) утврдуваат дека депресивноста и психичката оптовареност се предиктори на задоволството од животот кај негувателите на лицата со деменција, при што психичката оптовареност се јавува како посилен предиктор. Според истите автори, психичката оптовареност е негативно поврзана со степенот на општо здравје кај негувателите. Abdollahpour и соработниците (2015), исто така, наоѓаат дека психичката оптовареност е најсилен предиктор на квалитетот на живот кај негувателите на лица со деменција. Поголемата психичка оптовареност е поврзана со когнитивните и физичките нарушувања на лицето со деменција, бројот на часови поминати во грижа, бројот на задачи, и поизразена е кај сопружници отколку кај деца на лицата со деменција (Pinquart \& Sörensen, 2004). Проблематичното однесување кај лицето со деменција се јавува како најсилен предиктор на психичката оптовареност (Clyburn, Stones, Hadjistavropoulos, \& Tuokko, 2000; Pinquart \& Sörensen, 2004). Покрај тоа, психичката оптовареност е поголема кога неформалната социјална поддршка е ниска (Clyburn et al., 2000), кога негувателите се преоптоварени, се чувствуваат заробени во улогата, имаат ниска самодоверба, нарушен квалитет на односот со лицето за кое се грижат, искусуваат неповолни животни искуства и се жени (Campbell et al., 2008).

Социјалната поддршка во процесот на грижа за лице со деменција се јавува како истакната потреба на негувателите (Ducharme et al., 2014; Wackerbarth \& Johnson, 2002). Но, негувателите доживуваат послаба социјална поддршка во споредба со лица кои не се негуватели и имаат помалку можности за социјални активности и извршување активности кои им предизвикуваат задоволство. (Löfgren et al., 1992; Veenstra , Ruth Mark \& Jütten, 2018). Во моделот на добросостојба кај негуватели, покрај психичката оптовареност и часовите поминати во грижа Chappel и Reid (2002) ја вбројуваат и неформалната социјална поддршка како директен предиктор.

Негувателите кои имаат стабилна и висока социјална поддршка имаат подобро расположение и се позадоволни од животот. Покрај тоа, имаат повисока самооценка на физичкото здравје, пониска употреба на психотропни лекарства, помал број на лекарски посети, помал број на симптоми на стрес и повисоко ниво на позитивен афект (Clipp \& George, 1990). Поврзаност помеѓу социјалната поддршка и задоволството од животот наоѓат и Haley и соработниците (2003). Повисоките нивоа на социјална поддршка се поврзани со 
повисоки проценки на физичкото здравје (Gold et al., 1995; Goode, Haley, Roth \& Ford 1998; Pinquart \& Sörensen, 2007), а задоволството од социјалната поддршка предвидува подобра превенција и чување на физичкото здравје (Goode et al., 1998). Недостатокот на позитивна социјална поддршка и зачестените конфликти се поврзани со нарушено ментално здравје кај негувателите на лица со деменција (Butterworth et al., 2010).

Социјалната поддршка најчесто има улога на медијатор во односот помеѓу грижата за лице со деменција и квалитетот на живот, затоа што е поврзана со пониски нивоа на депресивност (Au et al., 2009; Butterworth et al., 2010; Clyburn et al., 2000; Haley et al., 1996; Sandoval, Tamiya, Lloyd-Scherlock, Noguchi, 2019; Schulz \& Williamson, 1991), стрес (Pakenham, 2001; Sander, High, Hannay, Sherer, 1997) и психичка оптовареност (Chiou, Chang, Chen, Wang, 2009; Coen Swanwick, O'Boyle \& Coakley, 1997; Davis et al., 2009).

Како медијаторска варијабла, често се јавува и стилот на справување со стрес. Избегнувачкиот стил на справување и пониското ниво на перципирана поддршка се поврзани со полоша адаптација на хронична болест (White, 1992), а пристапувачкиот стил на справување е поврзан со повисоко ниво на задоволство од животот и пониско ниво на депресивност (Haley et al., 1996), како и подобри исходи поврзани со здравјето (Goode et al., 1998). Mausbach и соработниците (2013, според Hawken, Turner-Cobb, \& Barnett, 2018) утврдиле дека негувателите употребуваат помалку „позитивни“ стратегии (вклучување во пријатни активности и барање социјална поддршка), а повеќе „негативни“ стратегии за справување (како себеобвинување и избегнување), имаат полоши психосоцијални исходи и прилагодување. Фантазирањето и одрекувањето како избегнувачки стратегии кај негувателите се поврзани со повисок психолошки стрес (Pakenham \& Bursnall, 2006).

Оттука, врз основа на прегледот на емпириските наоди, се претпоставува дека повисок степен на психичка оптовареност и депресивност, како и понизок степен на социјална поддршка и пристапувачки стил на справување предвидуваат полош квалитет на живот кај неформалните негуватели на лица со деменција.

\section{Метод}

Примерок и ӣосӣаӣка

Во истражувањето беше користен пригоден примерок составен од 106 неформални негуватели на лице со деменција. Просечната возраст на испитаниците е 45 години $(S D=14,3)$, а на лицето за коешто се грижат е 77 години $(S D=11,4)$. Во просек, изминати се 4 години од поставувањето на дијагнозата $(S D=3,6)$, а испитаниците се во улога на негуватели 3,5 години $(S D=3,9)$, по 12 часови во денот 
$(S D=8,5)$. За лицето со деменција, во просек се грижат уште тројца негуватели (формални или неформални), по 45 часови во неделата $(S D=47,6)$. Осумдесет и еден процент од испитаниците се жени. Според местото на живеење 33,1 \% се од РС Македонија, 47,2 \% се од САД/Канада, 14,2 \% се од Западна Европа, 2,8 \% се од Австралија и 4,7 \% се од други земји. Над половина од испитаниците $(54,7 \%)$ се грижат за родител, 15,7 \% се грижат за сопружник, 16 \% се грижат за баба/дедо, а останатите се грижат за лице од друг вид роднинска/ пријателска врска. Притоа, 57,5 \% живеат заедно со лицето за кое се грижат, а кај 65,1 \% грижата е поделена со друго лице. Во однос на социоекономскиот статус, 40,6 \% од испитаниците се вработени, а 65,1 \% изјавиле дека имаат средни приходи.

Истражувањето беше спроведено на интернет, од март до септември 2020 година, преку платформата Google Form, а испитаниците беа регрутирани преку групите за поддршка на негуватели за лица со деменција на социјалните медиуми. Учеството во истражувањето беше анонимно и доброволно, со давање информирана согласност.

\section{Мерни инсиируменйи}

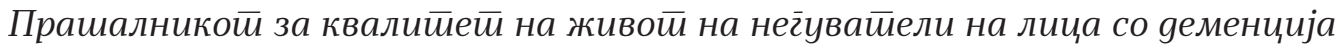
(C-DEMQOL, Dementia Carers Quality of Life, Brown et al., 2019) е инструмент специфично наменет за мерење на квалитетот на живот кај негуватели на лица со деменција како мултидимензионален конструкт составен од: чувство на поддршка, добросостојба на негувателот, однос со лицето со деменција, верба во иднината и задоволеност на личните потреби. Се состои од 30 ајтеми (по 5 за секоја димензија), а се одговара на скала од 1 до 5, при што понудените алтернативи варираат согласно содржината на ајтемите. Можниот опсег на скорови е 30 - 150, при што повисок скор означува повисок квалитет на живот кај негувателот. Релијабилноста на мерката, според валидациската студија, изнесува $\omega=.97$, а за примерокот во ова истражување $\alpha=.94$.

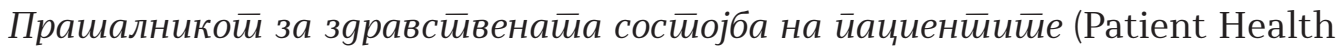
Questionnaire, PHQ-9, Kroenke, Spitzer, \& Williams, 2001) беше употребен за мерење на девет индикатори на депресивност, согласно ДСМ-4. Од испитаниците се бара да означат колку често се чувствувале на опишаниот начин во претходните две недели и тоа, од 0 -„ниту еднаш“ до 3 -„,скоро секој ден“. Опсегот на скоровите е 0 - 27, при што повисок скор означува повисок степен на депресивност. Авторите соопштуваат задоволителна релијабилност на прашалникот $(\alpha=.89)$, а на дадениот примерок беше утврден Кронбах-алфа-коефициент .91.

Социјалната поддршка беше мерена со скратената верзија на Скалайа за иерцийирана йоggрика (11-Item Perceived Support Scale, Krause, 1997), соста- 
вена од 11 ајтеми кои укажуваат на три аспекти на перципираната социјална поддршка: емоционална (4 ајтеми), информативна (4 ајтеми) и опиплива (3 ајтеми). Од испитаниците се бара да означат колку често во минатата година доживеале опишано однесување од страна на друг, и тоа од 1 -„никогаш“ до 4 -„многу често“. Опсегот на скорови е 11 - 44. Кронбах-алфа-коефициентот во оригиналната валидациска студија изнесува .82, а за дадениот примерок $\alpha=.91$.

Психичката оптовареност се мереше преку кратката верзија на Инйервјуйо

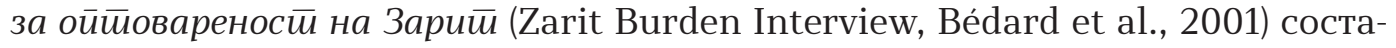
вена од 12 ајтеми. За секој ајтем испитаникот треба да означи колку често се чувствува на опишаниот начин и тоа од 1 -„никогаш“ до 5 -„скоро секогаш“. Опсегот на скорови е 12 - 60. Кронбах-алфа-коефициентот на оригиналната скала изнесува .88, а за дадениот примерок $\alpha=.89$.

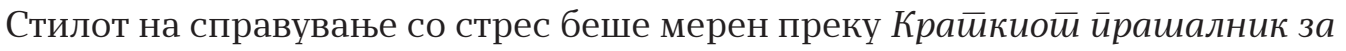

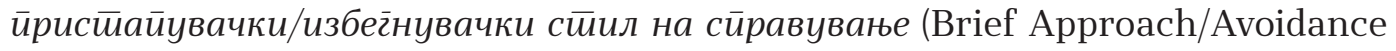
Coping Questionnaire, Finset et al., 2002), што се состои од 12 ајтеми. Опсегот на скорови е 12 -60, меѓутоа третирањето на мерката како еднодимензионална покажа ниска релијабилност. Спроведената факторска анализа покажа дека задоволително факторско заситување за пристапувачкиот стил на справување имаат само ајтемите 2 - 6, така што за целите на ова истражување беа искористени само овие ајтеми. Испитаниците одговараат преку изјаснување на степенот на согласност со секое тврдење и тоа од 1 -„воопшто не се согласувам“ до 5 - „целосно се согласувам“. Кронбах-алфа- коефициентот на оригиналната мерка изнесува .68, а за дадениот примерок $\alpha=.70$.

За да се измери степенот на симптомите кај лицето со деменција користени беа скалите за когнитивен статус и проблематично однесување (Pearlin, Mullan, Semple \& Skaff, 1990). На скалата за когнитивен статус, испитаникот треба да означи колку е тешко за лицето со деменција да се однесува на опишаниот начин, и тоа од 1 -„воопшто не е тешко“ до 5 -„воопшто не може да го направи тоа“. Опсегот на скорови е 8 - 40, при што повисок скор укажува на повисоко когнитивно опаѓање. На скалата за проблематично однесување испитаникот треба да означи колку често се соочил/а со некое од опишаните однесувања во текот на изминатата недела и тоа од 1 -„ниту еден ден“ до 4 -„пет или повеќе денови“. Опсегот на скорови е 14 - 56 при што повисок скор укажува на почесто проблематично однесување кај лицето со деменција. Авторите наведуваат Кронбах-алфа-коефициент од .86 и .79 за скалите за когнитивен статус и проблематично однесување соодветно, а за дадениот примерок коефициентите беа .90, односно .83. 


\section{Резултати}

Увидот во дескриптивните статистики (табела 1) укажува дека отстапување од нормалната дистрибуција по хоризонтала се забележува кај варијаблите депресивност, социјална поддршка (позитивен скјунес) и кај варијаблата пристапувачки стил на справување со стрес (негативен скјунес). Отстапување по вертикала се забележува кај варијаблите: квалитет на живот, депресивност, социјална поддршка, когнитивен статус и бихевиорални тешкотии кај лицето со деменција што укажува на платикуртична дистрибуција.

Табела 1. Дескриптивни статистци за испитуваните варијабли

\begin{tabular}{lcccccccc}
\hline & M & SD & Min & Max & \multicolumn{2}{c}{ Skewness (SE) } & Kurtosis (SE) \\
\hline Квалитет на живот & 81.84 & 20.85 & 39 & 129 & .02 & .24 & -.69 & .47 \\
Психичка оптовареност & 29.40 & 10.63 & 2 & 56 & .02 & .24 & -.15 & .47 \\
Депресивност & 10.75 & 7.03 & 0 & 25 & .37 & .24 & -.85 & .47 \\
Социјална поддршка & 25.22 & 8.78 & 10 & 44 & .27 & .24 & -.80 & .47 \\
Пристапувачки стил на & 17.179 & 4.32 & 6 & 25 & -.68 & .24 & -.3 & .47 \\
справување & & & & & & & & \\
Когнитивен статус & 20.07 & 8.94 & 1 & 38 & .06 & .24 & -.85 & .47 \\
Бихевиорални тешкотии & 31.43 & 8.79 & 14 & 51 & .07 & .24 & -.65 & .47 \\
\hline
\end{tabular}

За тестирање на хипотезата беше спроведена хиерархиска регресивна анализа при што во првиот блок како контролна беше внесена варијаблата место на живеење ( 1 = РСM, 0 = други земји), во вториот блок со иста улога беа внесени когнитивниот статус и бихевиоралните тешкотии на лицето со деменција, а во третиот блок беа вклучени сите тестирани предиктори.

Табела 2: Наоди од спроведената регресивна анализа

\begin{tabular}{|c|c|c|c|c|c|c|c|}
\hline Модел & \multirow{2}{*}{$\frac{\mathrm{B}}{85.879}$} & \multirow{2}{*}{$\frac{\mathrm{SE}}{3.615}$} & \multirow[t]{2}{*}{$\beta$} & \multirow{2}{*}{$\begin{array}{c}\text { Sig. } \\
<.001\end{array}$} & \multirow{2}{*}{$\frac{\mathrm{R}^{2}}{.017}$} & \multirow{2}{*}{$\frac{\Delta \mathrm{R}^{2}}{.017}$} & \multirow{2}{*}{$\begin{array}{c}\mathrm{F} \\
1.81\end{array}$} \\
\hline 1 (Константа) & & & & & & & \\
\hline \multirow{2}{*}{$\begin{array}{l}\text { Место на живеење } \\
\text { (Константа) }\end{array}$} & 5.865 & 4.357 & \multirow[t]{2}{*}{.131} & .181 & & \multirow{4}{*}{.203} & \multirow{4}{*}{$9.60^{* * *}$} \\
\hline & \multirow{3}{*}{$\begin{array}{c}125.550 \\
-.718 \\
-.599\end{array}$} & 8.355 & & $<.001$ & \multirow[t]{3}{*}{.220} & & \\
\hline \multirow{2}{*}{$\begin{array}{l}\text { Бихевиорални тешкотии } \\
\text { Когнитивен статус }\end{array}$} & & .237 & \multirow{2}{*}{$\begin{array}{l}-.303 \\
-.257\end{array}$} & .003 & & & \\
\hline & & .267 & & .027 & & & \\
\hline \multirow{5}{*}{$\begin{array}{l}\text { (Константа) } \\
\text { Психичка оптовареност } \\
\text { Депресивност } \\
\text { Социјална поддршка } \\
\text { Пристапувачки стил на } \\
\text { справување }\end{array}$} & 133.820 & 8.236 & & $<.001$ & .749 & .528 & $41.70^{\star \star *}$ \\
\hline & -1.228 & .149 & -.626 & $<.001$ & & & \\
\hline & -.653 & .208 & -.220 & .002 & & & \\
\hline & .333 & .137 & .140 & .017 & & & \\
\hline & .146 & .280 & .030 & .603 & & & \\
\hline
\end{tabular}

Резултатите (табела 2) покажуваат дека местото на живеење не е значаен предиктор на квалитетот на живот кај неформалните негуватели на лица со деменција $(\beta=0,13 ; p>$.05). Кога во вториот блок беа додадени когнитивниот 
статус и бихевиоралните тешкотии предиктивната моќ на моделот се зголеми за 20,3 \% ( $\Delta R 2=.203 p<.001)$. Притоа, двете контролни варијабли поврзани со симптомите на болеста на лицето со деменција се значајни предиктори на квалитетот на живот кај неформалните негуватели (когнитивен статус $\beta=-.24$; $p<.05$, бихевиорални тешкотии $\beta=-.30 ; p<.01)$.

Предикторските варијабли внесени во третиот блок, самостојно објаснуваат 52,8 \% од варијансата на варијаблата квалитет на живот кај неформалните негуватели на лица со деменција. Притоа, најголем придонес има варијаблата психичка оптовареност $(\beta=.63 ; p<.001)$, а помал депресивноста $(\beta=-.22$; $\mathrm{p}<.01)$ и социјалната поддршка $(\beta=.14 ; p<.05)$, додека пристапувачкиот стил на справување не се потврди како значаен предиктор на квалитетот на живот кај неформалните негуватели $(\beta=.03 ; p>.05)$

\section{Дискусија}

Целта на ова истражување беше да се откријат и разберат некои од факторите кои го одредуваат квалитетот на живот кај неформалните негуватели на лица со деменција. Беше утврдено дека понискиот степен на депресивност и психичка оптовареност, а повисокиот степен на социјална поддршка предвидуваат подобар квалитет на живот кај неформалните негуватели на лица со деменција. Пристапувачкиот стил на справување со стрес не е значаен предиктор на квалитетот на живот со што истражувачката хипотеза делумно се потврди.

Значајна поврзаност на психичката оптовареност, депресивноста и социјалната поддршка со квалитетот на живот или неговите аспекти е утврдена и во голем број минати истражувања. Некои автори како најзначаен предиктор на квалитетот на живот ја идентификуваат психичката оптовареност (Abdollahpour et al., 2015b; McConaghy \& Caltabiano, 2005), а други депресивноста (Takai et al., 2011), но и двете варијабли се меѓу најчесто идентификуваните детерминанти на квалитетот на живот кај неформалните негуватели на лица со деменција (Alfakhri et al., 2018; Bruvik et al., 2012; Clark \& Bond, 2000; Novelli \& Caramelli, 2010; Papastavrou et al., 2014; Santos et al., 2014; Srivastava et al., 2016; Van der Lee et al., 2014).

Според најновите прегледи на истражувањата, чиј фокус на интерес е психичката оптовареност на негувателите (Cheng, 2017), барањата кои се поставуваат пред негувателите имаат најголем удел во чувството на психичка оптовареност. Едно од главните обележја на деменциите е намалувањето на функционалноста на човекот што се идентификува преку намалената способност да ги извршува секојдневните активности (Desai, Grossberg \& Seth, 2004). Во однос на ова, 
М. ТАНЕСКА: ПСИХИЧКА ОПТОВАРЕНОСТ, ДЕПРЕСИВНОСТ, СОЦИЈАЛНА ПОДДРШКА И СПРАВУВАҢЕ...

Mioshi и соработниците (2013) откриваат дека без разлика дали се работи за Алцхајмерова деменција или фронтотемпорална деменција кај негувателите се забележува истиот образец на зголемување на оптовареноста со напредокот на болеста. Демографските податоци покажуваат дека испитаниците во просек минуваат 12 часови од денот во грижа за лицето со деменција што е повеќе од 2/3 од активниот ден. Наго и соработниците (2014) утврдуваат дека часовите поминати во надгледување на лицето за кое се грижат, позитивно корелираат со чувството на оптовареност. Притоа, просечната возраст на испитаниците (45 години) покажува дека повеќето од нив сѐ уште се во работен однос и имаат деца за коишто треба да се грижат истовремено, правејќи ги дел од т.н. „сендвич генерација“. Наоди од претходни истражувања покажуваат дека меѓу вработените негуватели има поголем апсентизам, намалени работни обврски, одбиени унапредувања и откази со цел да се справат со негувателските обврски (Lilly, Laporte \& Coyte, 2007 според Liu et al., 2019). Негувателите кои испуштале денови од работа изјавуваат дека имаат конфликтни улоги и страдаат од поголема психолошка затегнатост (Barling, MacEwan, Kelloway \& Higgingottom, 1994; Orry et al., 1999 според Liu et al., 2019). Дополнително, 81 \% од испитаниците се жени и може да се очекува дека врз нив „паѓаат“ најголем дел од обврските во домот што придонесува кон чувството на оптовареност и е во склад со наодите дека жените негуватели, општо, имаат повисоки нивоа на оптовареност (Brodaty et al., 2014; Hughes et al., 2014; H. Kim, Chang, Rose \& Kim, 2012; Van der Lee, Bakker, Duivenvoorde n\& Dröes, 2014). Постојат повеќе наоди кои ја поддржуваат поврзаноста на функционалните нарушувања и поголемата зависност на лицето со деменција со психичката оптовареност (Ahmed Hamza, Mahmoud, Adib Rafaat, \& Adel Abbas Mohamed, 2018; Kang et al., 2014; Razani et al., 2007). Од друга страна, когнитивниот статус на лицето за кое се грижат, дополнително придонесува кон чувството на оптовараност на негувателите (Brodaty et al., 2014; Cheng, 2017; Gallagher et al., 2011.) и чувството на депресивност (Omranifard, Haghighizadeh \& Akouchekian, 2018) делумно поради фактот што го преземаат процесот на донесување важни одлуки за лицето кое ја губи способноста само да одлучува и независно да функционира. Garvelink и соработниците (2016) од метаанализата на истражувањата на процесот на одлучување кај неформалните негуватели заклучуваат дека негувателите чувствуваат оптовареност од процесот на одлучување, одговорност за одлуката, амбивалентност, тешкотија, неудобност и стрес. Невропсихијатриските симптоми и промените во личноста кај лицето за кое се грижат се сметаат за најсилни предиктори на психичката оптовареност, затоа што се непредвидливи, тешки за справување, неретко агресивни и хостилни, го нарушуваат мирот и 
сонот на негувателите (Cheng, 2017). Интензитетот и бројот на проблематични однесувања, стадиумот на болеста се, исто така, поврзани со депресивноста кај негувателите (Haley et al., 2003; R Schulz \& Williamson, 1991; Yates, Tennstedt, \& Chang , 2009; Zanetti et al., 1998). Во ова истражување, токму поради тоа проблематичните однесувања и когнитивниот статус беа вклучени како контролни варијабли, при што се потврди дека се значајни предиктори на квалитетот на живот на неформалните негуватели.

Преку симптомите на болеста може да се објасни и дел од чувството на депресивност кај негувателите. Постепената личносна детериорација и губењето на сеќавањето кај негувателите често се доживува како постепена смрт кај лицето за кое се грижат и е поврзана со т.н. „претсмртно жалење“ (Lindauer \& Harvath, 2014), типично за лица кои се грижат за близок со деменција поради асинхроност помеѓу физичката и психолошката смрт, нејасната траекторија на болеста, нарушената комуникација и емоционалните варијации. Губењето на значајна личност кај негувателите е поврзано и со чувство на загуба на себеси, односно сликата за себе и сопствениот идентитет (Beeson, 2003). Постепената загуба постепно отвора и празнина во личносниот и социјалниот систем на негувателот кој, покрај другото, губи и важен извор на лична валидација и поддршка. Претсмртното жалење е поврзано со депресивност (Adams \& Sanders 2004 според Lindauer \& Harvath, 2014), психичка оптовареност (Cheung et al., 2018,; Holley \& Mast 2009 според Lindauer \& Harvath 2014) и пониска психолошка добросостојба (Cheung et al., 2018). Личносната детериорација на лицето за кое се грижат вклучува и губење на способноста за комуникација и можноста за изразување на чувствата и мислите и неминовно води до чувства на осаменост кај негувателот, особено ако се работи за партнер (Siriopoulos et al., 1999), а чувството на осаменост е значаен предиктор на чувството на депресивност (Beeson, 2003).

Со оглед на тоа што поголемиот дел од испитаниците се грижат за родител, можна е појавата и на феноменот „промена на улоги“ за кој е утврдено дека неповолно влијае врз квалитетот на живот. Промената на улогите води до нарушување на стабилноста на системот и бара големо прилагодување (Hindin, 2007). King, Ainsworth, Ronen Hartke, 2010 промената на улогите, како проблем на дијадниот однос помеѓу негувателот и лицето за кое се грижи ја сместуваат во категоријата на најстресни проблеми поврзани со негувателството, a Siriopolous и соработниците (1999) идентификуваат тешкотии поврзани со промената на улоги дури и кај сопрузите на жени кои имаат деменција.

Социјалната поддршка има значајна, но многу пониска предиктивна моќ за квалитетот на живот кај неформалните негуватели. Прегледот на литера- 
турата покажува дека социјалната поддршка многу почесто се среќава како медијаторска варијабла, отколку како непосреден предиктор на квалитетот на живот (Khusaifan \& El Keshky, 2017; Kong, Hu, Yao, Zhao, 2019) и е посилен фактор за депресивноста (Butterworth et al., 2010; Chai et al., 2018; Clyburn et al., 2000) како и психичката оптовареност. Во моделот кој го објаснува процесот на стрес кај неформалните негуватели, социјалната поддршка заедно со справувањето се идентификувани како најзначајни медијатори на ефектот на примарните и секундарните стресори (Pearlin et al., 1990). Недостатокот на социјална поддршка е еден од најзначајните предиктори на чувството на депресивност кај неформалните негуватели (Haley et al., 2003; Sandoval et al., 2019). Farina и соработниците (2018), во детерминантите на квалитетот на живот кај неформалните негуватели ја вбројуваат евалуацијата на поддршката, особено степенот до кој ја вреднуваат понудената поддршка и дали перципираат дека ги достигнува барањата. Најценета е поддршката од другите членови на семејството, особено практичната помош и споделеното одлучување. Авторите утврдиле дека недостатокот на социјална поддршка води до стрес и до чувство на предаденост што има негативен ефект врз квалитетот на живот. Dam и соработниците (2018) во квалитативната студија за перспективите на брачните негуватели и нивното социјално опкружување откриваат дека негувателите кои добиваат поддршка доживуваат чувства на корисност, вредност и припаѓње.

Спротивно од тоа што беше претпоставено во истражувачката хипотеза, пристапувачкиот стил на справување не се утврди дека е значаен предиктор на квалитетот на живот, иако како таков е идентификуван во минати студии (Mausbach et al., 2013; Pakenham, 2001). Постојат одредени истражувања кои зборуваат за пониската адаптивност на пристапувачките стратегии за справување со стрес кај негувателите на лица со деменција. Едно објаснување е дека обидите за активно справување го намалуваат чувството на контрола кај неформалните негуватели (Ruiz-Robledillo \& Moya-Albiol, 2013). Обидите когнитивно и бихевиорално да се справат со стресорот, каква што е хроничната или прогресивната болест, врз којашто немаат контрола е поврзано со пониска добросостојба и поголем психолошки стрес (Wrosch, Scheier, Miller, Schulz, \& Carver, 2003 според Ruiz-Robledillo \& Moya-Albiol, 2013). Следствено, избегнувањето може да биде поадаптивна форма на себерегулација во вакви ситуации (Wrosch \& Scheier, 2003 Ruiz-Robledillo \& Moya-Albiol, 2013). Друго објаснување е дека активните обиди за справување со стресот, може дополнително да ја зголемат психичката оптовареност поради прекумерното вложување во справувањето, без разлика дали е насочено кон проблемот или кон емоциите (Pakenham, 2001). Не треба да се занемари и можноста ваквиот 
наод да е резултат на проблематичните психометриски карактеристики на користената скала за пристапувачко справување.

Потребно е да се земе предвид и контекстот во кој е направено ова истражување: пандемијата на КОВИД-19. На дополнителни прашања вклучени во истражувањето, секој трети испитаник изјави дека чувствува поголема оптовареност од почетокот на пандемијата, а секој втор дека проблематичните однесувања кај лицето за кое се грижи се посилни од почетокот на пандемијата. Ограничениот обем на истражувања на оваа тема покажува дека специфичните проблеми со кои се соочуваат негувателите за време на пандемијата се поврзани пред сѐ, со заштита на лицето за кое се грижат од инфицирање и внимавање на нивното здравје, како и заштита на сопственото здравје, добросостојба, а потоа и менаџирање на променетите обврски поврзани со грижата, домот и работата и справување со засилените бихевиорални симптоми кај лицето за кое се грижат. Сето ова е пропратено со грижата дека тие или лицето со деменција ќe бидат заразени. Како најистакнати потреби се: потреби за консултација со специјалист, пристап до лекарства, стимулирање на лицето со деменција во домот, помош за лицето со деменција во домот и флексибилна имплементација на мерките (Vaitheswaran et al., 2020).

Од наодите на ова истражување може да се заклучи дека грижата за лице со деменција има силно влијание врз сите домени на квалитетот на живот кај неформалните негуватели. Овие сознанија треба да се земат предвид при создавањето политики за менаџирање на деменцијата на општествено ниво. Менаџирањето на деменциите треба да биде преку системот: лице со деменција - негувател -професионални лица. Пристапот треба да биде интердисциплинарен и во третманот да бидат вклучени лица од медицинските струки (невролози, психијатри, радиолози, медицински сестри, окупациони терапевти, физиотерапевти, фармаколози) како и од немедицинските струки (социјални работници, невропсихолози, психотерапевти, правници). Само на овој начин може да се воспостави стабилна мрежа на ефикасна и сеопфатна поддршка и за лицата со деменција и за нивните семејства.

Кога станува збор за неформалните негуватели, фокусот треба да биде насочен кон намалување на оптовареноста преку различни форми на системска поддршка. Тука, приоритет се: отворањето дневни центри во кои ќе работи тим од релевантни професионалци и во кои ќе има значајни и стимулативни активности за лицето со деменција, но и поддршка за негувателите (организација на групи за поддршка, психолошко советување, обучување и информирање). Обучувањето на негувателите е исто така исклучително важен елемент на формалната поддршка. Од една страна, обуката би ги снабдила негувателите 
М. ТАНЕСКА: ПСИХИЧКА ОПТОВАРЕНОСТ, ДЕПРЕСИВНОСТ, СОЦИЈАЛНА ПОДДРШКА И СПРАВУВАњЕ...

со вештини за пружање посоодветна грижа, а од друга страна со вештини за посоодветно справување со сопствените доживувања на процесот и учење адаптивни стратегии за справување со стрес. Психолошката помош, исто така би им овозможила на негувателите полесно да ги препознаат позитивните аспекти на грижата, кои се значаен ресурс за справување. Дополнително, потребно е да се обезбеди и можност за достапна професионална нега во рамки на домот за лица кои од какви било причини одбиваат да одат во дневни центри, како и зголемување на пристапноста во домовите за стари лица.

Друг важен аспект е и подобрување на квалитетот на здравствената нега, како дијагностика така и постдијагностички третман на лицата со деменција. Ова вклучува зголемување на релевантните кадри, подобрување на технологиите за дијагностика и зголемување на ефикасноста на здравствениот систем воопшто што ќе овозможи побрзо стигнување до дијагноза и постдијагностички третман. Постдијагностичкиот третман треба да почнува пред сѐ, со снабдување на лицето со деменција и семејството со сите информации кои ќе им бидат потребни. Дијагнозата деменција многу често се доживува како „смртна казна“ и важно е да се ослободи првичната анксиозност преку јасно комуницирање на очекувањата, можностите и насоките за поефикасна грижа. Покрај зголемувањето на бројот на кадрите, потребна е и сеопфатна едукација на постоечките кадри на сите нивоа на здравствениот систем, особено на матичните лекари што ќе овозможи порана детекција на раните симптоми и третман прилагоден за лица кои имаат деменција. Акцентот треба да се стави на нефармаколошките третмани кои се покажуваат поефикасни во справувањето со бихевиоралните и невропсихијатриските симптоми, истовремено елиминирајќи ги неповолните негативни ефекти на лекарствата.

На макрониво, важно е да се работи на подигнување на свеста за деменцијата. Ова пред сѐ, би придонело кон порана идентификација на симптомите како отстапка од она што се смета за нормално стареење поради што во најголем дел од случаите дијагностицирањето се случува дури кога симптомите се поизразени, во средните стадиуми од болеста. Од аспект на негувателите, раната дијагноза би овозможила поадекватна адаптација на семејството кон новонастанатата ситуација, но и вклучување на лицето со деменција во планирање на грижата и носењето важни одлуки што би го намалило товарот од негувателите и грижите за иднината и одлуките кои треба да се носат. Зголемувањето на свеста за товарот кој го поставува деменцијата врз негувателите може да влијае кон менувањето на перцепциите дека грижата за лице со деменција е нешто нормативно и „природно“ во животниот циклус на луѓето и зголемување на разбирањето дека е процес кој бара големи вложувања и промени, и сериозно 
ги засега здравјето и добросостојбата на целото семејство. Ваквата промена на перцепциите може да влијае и врз зголемување на свеста за неопходноста од формална и неформална поддршка за негувателите на лица со деменција.

Со стареењето на светската популација, стапките на деменција растат со што станува сѐ поголем здравствен, економски и социјален проблем. Неадекватното справување со деменциите и недоволната поддршка на негувателите води кон детериорација на нивното здравје што, во крајна мера, продуцира поголем товар за здравствениот систем од една страна, но и влијае врз економијата преку редуцирање на работоспособното население и намалување на продуктивноста на вработените негуватели. Деменцијата не е проблем кој може да се разгледува и третира во изолација и само системскиот, интердисциплинарен пристап води кон подобрување на квалитетот на живот на лицата со деменција и на нивните семејства.

За прв пат во Република Северна Македонија е спроведено истражување во кое примерокот го сочинуваат негуватели на лица со деменција и истото овозможи добивање појасна слика за нивните искуства и специфични потреби, но и даде впечаток дека постои интерес за оваа тема. Ваквото посветување внимание беше исклучително позитивно примено од страна на испитаниците.

Ограничувањата на истражувањето се поврзани, главно со начинот на формирање на примерокот, инструментите и методот на прибирање податоци. Примерокот на истражувањето е пригоден, што ја ограничува можноста за генерализација на наодите. Мерните инструменти не се стандардизирани за поголем дел од примерокот што може да се одрази врз нивната осетливост. Користењето англиска и македонска верзија од прашалникот може да придонесе кон различен начин на реагирање на исти ајтеми кај испитаниците поради лингвистичките разлики. Конечно, истражувањето е спроведено на интернет што исклучува дел од примерокот кој има ограничени способности за користење технологија и пристап до неа.

Со оглед на тоа што оваа тема е неистражена во Република Северна Македонија, потребни се идни истражувања кои ќе бидат понасочени кон специфични аспекти на грижата за лице со деменција, поради тоа што во ова истражување беше насочено кон искуството во целост. Потребно е да се вклучат и испитаници од помалите градови и од руралните средини каде има уште поограничени системски ресурси, но и различна животна динамика, со цел да се евидентираат различни потреби и начини на справување. Земајќи предвид дека третманот на лица со деменција засега различни сегменти од општеството, од исклучителна корист би било интердисциплинарно истражување на оваа тема. 


\section{Литература}

Abdollahpour, I., Nedjat, S., Salimi, Y., Noroozian, M., \& Majdzadeh, R. (2015a).

Which variable is the strongest adjusted predictor of quality of life in caregivers of patients with dementia? Psychogeriatrics, 15(1), 51-57. https://doi. org/10.1111/psyg.12094

Ahmed Hamza, S., Mahmoud, H. F., Adib Rafaat, V., \& Adel Abbas Mohamed, A. (2018).The level of function of dementia patients has an impact on the caregiver Burden. Journal of Gerontology and Geriatric Research, 7(2). https://doi.org/10.4172/2167- 7182.1000464

Alfakhri, A. S., Alshudukhi, A. W., Alqahtani, A. A., Alhumaid, A. M., Alhathlol, O. A., Almojali, A. I., Alotaibi, M. A., \& Alaqeel, M. K. (2018). Depression among caregivers of patients with dementia. Inquiry (United States), 55. https://doi.org/10.1177/0046958017750432

Alzheimer's Society (2007) Dementia UK, London, Alzheimer's Society

Au, A., Lai, M. K., Lau, K. M., Pan, P. C., Lam, L., Thompson, L., \& GallagherThompson, D. (2009). Social support and well-being in dementia family caregivers: The mediating role of self-efficacy. Aging and Mental Health, 13(5), 761-768. https://doi.org/10.1080/13607860902918223

Bangerter, L. R., Griffin, J. M., Zarit, S. H., \& Havyer, R. (2019). Measuring the Needs of Family Caregivers of People With Dementia: An Assessment of Current Methodological Strategies and Key Recommendations. Journal of Applied Gerontology, 38(9), 1304-1318. https://doi. org/10.1177/0733464817705959

Bédard, M., Molloy, D. W., Squire, L., Dubois, S., Lever, J. A., \& O’donnell, M. (2001). The Zarit Burden Interview: A new short version and screening version. Gerontologist, 41(5), 652-657. https://doi.org/10.1093/ geront/41.5.652

Beeson, R. A. (2003). Loneliness and depression in spousal caregivers of those with Alzheimer's disease versus non-caregiving spouses. Archives of Psychiatric Nursing, 17(3), 135-143. https://doi.org/10.1016/S08839417(03)00057-8

Brodaty, H., Connors, M. H., Xu, J., Woodward, M., \& Ames, D. (2014). Predictors of institutionalization in dementia: A three year longitudinal study. Journal of Alzheimer's Disease, 40(1), 221-226. https://doi.org/10.3233/JAD131850

Brodaty, H., Woodward, M., Boundy, K., Ames, D., \& Balshaw, R. (2014). Prevalence and predictors of burden in caregivers of people with dementia. American Journal of Geriatric Psychiatry, 22(8), 756-765. https:// doi.org/10.1016/j.jagp.2013.05.004 
Brown, A., Page, T. E., Daley, S., Farina, N., Basset, T., Livingston, G., Budgett, J., Gallaher, L., Feeney, Y., Murray, J., Bowling, A., Knapp, M., \& Banerjee, S. (2019). Measuring the quality of life of family carers of people with dementia: development and validation of C-DEMQOL. Quality of Life Research, 28(8), 2299-2310. https://doi.org/10.1007/s11136-019-02186-w

Bruvik, F. K., Ulstein, I. D., Ranhoff, A. H., \& Engedal, K. (2012). The quality of life of people with dementia and their family carers. Dementia and Geriatric Cognitive Disorders, 34(1), 7-14. https://doi.org/10.1159/000341584

Butterworth, P., Pymont, C., Rodgers, B., Windsor, T. D., \& Anstey, K. J. (2010). Factors that explain the poorer mental health of caregivers: Results from a community survey of older Australians. Australian and New Zealand Journal of Psychiatry, 44(7), 616-624. https://doi. org $/ 10.3109 / 00048671003620202$

Campbell, P., Wright, J., Oyebode, J., Job, D., Crome, P., Bentham, P., Jones, L., \& Lendon, C. (2008). Determinants of burden in those who care for someone with dementia. International Journal of Geriatric Psychiatry, 23(10), 10781085. https://doi.org/10.1002/gps.2071

Chai, Y. C., Mahadevan, R., Ng, C. G., Chan, L. F., \& Md Dai, F. (2018). Caregiver depression: The contributing role of depression in patients, stigma, social support and religiosity. International Journal of Social Psychiatry, 64(6), 578- 588. https://doi.org/10.1177/0020764018792585

Chappel, N. L., \& Reid, C. R. (2002). Burden and Well-Being Among Caregivers: Examining the Distinction. The Gerontologist, 42(December), 772-780. https://doi.org/10.1093/geront

Cheng, S. T. (2017). Dementia Caregiver Burden: a Research Update and Critical Analysis. In Current Psychiatry Reports (Vol. 19, Issue 9, p. 64). Current Medicine Group LLC 1. https://doi.org/10.1007/s11920-017-0818-2

Cheung, D. S. K., Ho, K. H. M., Cheung, T. F., Lam, S. C., \& Tse, M. M. Y. (2018). Anticipatory grief of spousal and adult children caregivers of people with dementia. BMC Palliative Care, 17(1), 124. https://doi.org/10.1186/s12904018-0376-3

Chiou, C. J., Chang, H. Y., Chen, I. P., \& Wang, H. H. (2009). Social support and caregiving circumstances as predictors of caregiver burden in Taiwan. Archives of Gerontology and Geriatrics, 48(3), 419-424. https://doi. org/10.1016/j.archger.2008.04.001

Clark, M. S., \& Bond, M. J. (2000). The effect on lifestyle activities of caring for a person with dementia. Psychology, Health and Medicine, 5(1), 13-27. https:// doi.org/10.1080/135485000105972 
Clipp, E. C., \& George, L. K. (1990). Caregiver Needs and Patterns of Social Support.Journal of Gerontology, 45(3), S102-S111. https://doi.org/10.1093/ geronj/45.3.s102

Clyburn, D. L., Stones, J. M., Hadjistavropoulos, T., \& Tuokko, H. (2000). Predicting caregiver burden and depression in Alzheimer'sdisease. The Journals of Gerontology Series B: Psychological Sciences and Social Sciences, 55(1), S2-13. https://doi.org/10.1093/geronb/55.1.s2

Coen, R. F., Swanwick, G. R. J., O’Boyle, C. A., \& Coakley, D. (1997). Behaviour disturbance and other predictors of carer burden in Alzheimer's disease. International Journal of Geriatric Psychiatry, 12(3), 331-336. https://doi. org/10.1002/(SICI)1099-1166(199703)12:3<331::AID- GPS495>3.0.CO;2-J

Dam, A. E. H., Boots, L. M. M., Van Boxtel, M. P. J., Verhey, F. R. J., \& De Vugt, M.

E. (2018). A mismatch between supply and demand of social support in dementia care: A qualitative study on the perspectives of spousal caregivers and their social network members. International Psychogeriatrics, 30(6), 881892. https://doi.org/10.1017/S1041610217000898

Davis, L. C., Sander, A. M., Struchen, M. A., Sherer, M., Nakase-Richardson, R., \& Malec, J. F. (2009). Medical and psychosocial predictors of caregiver distress and perceived burden following traumatic brain injury. Journal of Head Trauma Rehabilitation, 24(3), 145-154. https://doi.org/10.1097/ HTR.0b013e3181a0b291

Desai, A. K., Grossberg, G. T., \& Sheth, D. N. (2004). Activities of daily living in patients with dementia: Clinical relevance, methods of assessment and effects of treatment. In CNS Drugs (Vol. 18, Issue 13, pp. 853-875). CNS Drugs. https://doi.org/10.2165/00023210-200418130-00003

Ducharme, F., Kergoat, M. J., Coulombe, R., Lvesque, L., Antoine, P., \& Pasquier, F. (2014). Unmet support needs of early-onset dementia family caregivers: A mixed-design study. BMC Nursing, 13(1). https://doi.org/10.1186/s12912014- 0049-3

Etters, L., Goodall, D., \& Harrison, B. E. (2008). Caregiver burden among dementia patient caregivers: A review of the literature. In Journal of the American Academy of Nurse Practitioners (Vol. 20, Issue 8, pp. 423-428). https://doi.org/10.1111/j.1745-7599.2008.00342.x

Farina, N., Page, T. E., Daley, S., Brown, A., Bowling, A., Basset, T., Livingston, G., Knapp, M., Murray, J., \& Banerjee, S. (2017). Factors associated with the quality of life of family carers of people with dementia: A systematic review. In Alzheimer's and Dementia (Vol. 13, Issue 5, pp. 572-581). Elsevier Inc. https://doi.org/10.1016/j.jalz.2016.12.010 
Finset, A., Steine, S., Haugli, L., Steen, E., \& Lærum, E. (2002). The Brief Approach/Avoidance Coping Questionnaire: Development and validation. Psychology, Health and Medicine, 7(1), 75-85. https://doi. org/10.1080/13548500120101577

Gallagher, D., Mhaolain, A. N., Crosby, L., Ryan, D., Lacey, L., Coen, R. F., Walsh, C., Coakley, D., Walsh, J. B., Cunningham, C., \& Lawlor, B. A. (n.d.). Current Topics in Care Dependence and Caregiver Burden in Alzheimer's Disease and Mild Cognitive Impairment. https://doi.org/10.1177/1533317510394649

Garvelink, M. M., Ngangue, P. A. G., Adekpedjou, R., Diouf, N. T., Goh, L., Blair, L., \& Légaré, F. (2016). A synthesis of knowledge about caregiver decision making finds gaps in support for those who care for aging loved ones. Health Affairs, 35(4), 619-626. https://doi.org/10.1377/hlthaff.2015.1375

Gold, D. P., Cohen, C., Shulman, K., Zucchero, C., Andres, D., \& Etezadi, J. (1995).

Caregiving and dementia: Predicting negative and positive outcomes for caregivers. International Journal of Aging and Human Development, 41(3), 183-201. https://doi.org/10.2190/RGYJ-5KA2-7THX-7BQ5

Goode, K. T., Haley, W. E., Roth, D. L., \& Ford, G. R. (1998). Predicting longitudinal changes in caregiver physical and mental health: A stress process model. Health Psychology, 17(2), 190-198. https://doi. org/10.1037/0278-6133.17.2.190

Haley, William E., LaMonde, L. A., Han, B., Burton, A. M., \& Schonwetter, R. (2003).Predictors of depression and life satisfaction among spousal caregivers in hospice: application of a stress process model. Journal of Palliative Medicine, 6(2), 215-224. https://doi. org/10.1089/109662103764978461

Haley, William E., Roth, D. L., Coleton, M. I., Ford, G. R., West, C. A. C., Collins, R. P., \& Isobe, T. L. (1996). Appraisal, coping, and social support as mediators of well-being in black and white family caregivers of patients with Alzheimer's disease. Journal of Consulting and Clinical Psychology, 64(1), 121-129. https://doi.org/10.1037/0022-006X.64.1.121

Haro, J. M., Kahle-Wrobleski, K., Bruno, G., Belger, M., Dell'Agnello, G., Dodel, R., Jones, R. W., Reed, C. C., Vellas, B., Wimo, A., \& Argimon, J. M. (2014). Analysis of burden in caregivers of people with Alzheimer's disease using self-report and supervision hours. Journal of Nutrition, Health and Aging, 18(7), 677-684. https://doi.org/10.1007/s12603-014-0500-x

Hawken, T., Turner-Cobb, J., \& Barnett, J. (2018). Coping and adjustment in caregivers: A systematic review. In Health Psychology Open (Vol. 5, Issue 2, p. 205510291881065). SAGE Publications Inc. https://doi. org/10.1177/2055102918810659 
Hindin, M. J. (2007). Role Theory. In The Blackwell Encyclopedia of Sociology. John Wiley \& Sons, Ltd. https://doi.org/10.1002/9781405165518.wbeosr078

Hughes, T. B., Black, B. S., Albert, M., Gitlin, L. N., Johnson, D. M., Lyketsos, C. G., \& Samus, Q. M. (2014). Correlates of objective and subjective measures of caregiver burden among dementia caregivers: Influence of unmet patient and caregiver dementia-related care needs.

International Psychogeriatrics, 26(11), 1875-1883. https://doi.org/10.1017/ S1041610214001240

Kang, H. S., Myung, W., Na, D. L., Kim, S. Y., Lee, J. H., Han, S. H., Choi, S. H., Kim,

S. Y., Kim, S., \& Kim, D. K. (2014). Factors associated with caregiver burden in patients with Alzheimer's disease. Psychiatry Investigation, 11(2), 152-159. https://doi.org/10.4306/pi.2014.11.2.152

Kasuya, R. T., Polgar-Bailey, P., \& Takeuchi, R. (2000). Caregiver burden and burnout: A guide for primary care physicians. Postgraduate Medicine, 108(7), 119-123. https://doi.org/10.3810/pgm.2000.12.1324

Keniş-Coşkun, Ö., Atabay, C. E., Şekeroğlu, A., Akdeniz, E., Kasil, B., Bozkurt, G., \& Karadağ-Saygı, E. (2019). The relationship between caregiver burden and resilience and quality of life in a Turkish pediatric rehabilitation facility. Journal of Pediatric Nursing. https://doi.org/10.1016/j.pedn.2019.10.014

Khusaifan, S. J., \& El Keshky, M. E. S. (2017). Social support as a mediator variable of the relationship between depression and life satisfaction in a sample of Saudi caregivers of patients with Alzheimer's disease. International Psychogeriatrics, 29(2), 239-248. https://doi.org/10.1017/ S1041610216001824

Kim, H., Chang, M., Rose, K., \& Kim, S. (2012). Predictors of caregiver burden in caregivers of individuals with dementia. Journal of Advanced Nursing, 68(4), 846-855. https://doi.org/10.1111/j.1365-2648.2011.05787.x

King, R. B., Ainsworth, C. R., Ronen, M., \& Hartke, R. J. (2010). Stroke caregivers: Pressing problems reported during the first months of caregiving. Journal of Neuroscience Nursing, 42(6), 302-311. https://doi.org/10.1097/ JNN.0b013e3181f8a575

Kong, L. N., Hu, P., Yao, Y., \& Zhao, Q. H. (2019). Social support as a mediator between depression and quality of life in Chinese community-dwelling older adults with chronic disease. Geriatric Nursing, 40(3), 252-256. https:// doi.org/10.1016/j.gerinurse.2018.10.014

Krause, N. (1997). Anticipated support, received support, and economic stress among older adults. Journals of Gerontology - Series B Psychological 
Sciences and Social Sciences, 52(6), 284-293. https://doi.org/10.1093/ geronb/52B.6.P284

Kroenke, K., Spitzer, R. L., \& Williams, J. B. W. (2001). The PHQ-9: Validity of a brief depression severity measure. Journal of General Internal Medicine, 16(9), 606-613. https://doi.org/10.1046/j.1525-1497.2001.016009606.x

Lindauer, A., \& Harvath, T. A. (2014). Pre-death grief in the context of dementia caregiving: A concept analysis. Journal of Advanced Nursing, 70(10), 21962207. https://doi.org/10.1111/jan.12411

Liu, Y., Dokos, M., Fauth, E. B., Lee, Y. G., \& Zarit, S. H. (2019). Financial Strain, Employment, and Role Captivity and Overload over Time among Dementia Family Caregivers. Gerontologist, 59(5), e512-e520. https://doi.org/10.1093/ geront/gnz099

Löfgren, A. -C, Bucht, G., Eriksson, S., \& Winblad, B. (1992). A Comparative Study of the Social Conditions of Spouses of Long Term Patients Cared For Either in Nursing Homes or Home Care. Scandinavian Journal of Caring Sciences, 6(1), 45-52. https://doi.org/10.1111/j.1471-6712.1992.tb00122.x

Markowitz, J. S., Gutterman, E. M., Sadik, K., \& Papadopoulos, G. (2003). HealthRelated Quality of Life for Caregivers of Patients with Alzheimer Disease.

Alzheimer Disease and Associated Disorders, 17(4), 209-214. https://doi. org/10.1097/00002093-200310000-00003

Mausbach, B. T., Chattillion, E. A., Roepke, S. K., Patterson, T. L., \& Grant, I. (2013).

A comparison of psychosocial outcomes in elderly Alzheimer caregivers and noncaregivers. American Journal of Geriatric Psychiatry, 21(1), 5-13. https:// doi.org/10.1016/j.jagp.2012.10.001

McConaghy, R., \& Caltabiano, M. L. (2005). Caring for a person wih dementia: Exploring relationships between perceived burden, depression, coping and well- being. Nursing and Health Sciences, 7(2), 81-91. https://doi. org/10.1111/j.1442- 2018.2005.00213.x

Mioshi, E., Foxe, D., Leslie, F., Savage, S., Hsieh, S., Miller, L., Hodges, J. R., \& Piguet, O. (2013). The impact of dementia severity on caregiver burden in frontotemporal dementia and alzheimer disease. Alzheimer Disease and Associated Disorders, 27(1), 68-73. https://doi.org/10.1097/ WAD.0b013e318247a0bc

Moreno, J. A., Nicholls, E., Ojeda, N., De los Reyes-Aragón, C. J., Rivera, D., \& Arango-Lasprilla, J. C. (2015). Caregiving in Dementia and its Impact on Psychological Functioning and Health-Related Quality of Life: Findings from a Colombian Sample. Journal of Cross-Cultural Gerontology, 30(4), 393-408. https://doi.org/10.1007/s10823-015-9270-0 
М. ТАНЕСКА: ПСИХИЧКА ОПТОВАРЕНОСТ, ДЕПРЕСИВНОСТ, СОЦИЈАЛНА ПОДДРШКА И СПРАВУВАҢЕ...

Nogueira, M. M. L., Neto, J. P. S., Sousa, M. F. B., Santos, R. L., Rosa, R. D. L., Belfort, T., Torres, B., \& Dourado, M. C. N. (2015). Spouse-caregivers' quality of life in Alzheimer's disease. International Psychogeriatrics, 27(5), 837-845. https://doi.org/10.1017/S1041610214002646

Novelli, M. M. P. C., \& Caramelli, P. (2010). A influência das alterações de comportamento e do desempenho funcional sobre a qualidade de vida na doença de Alzheimer. Dementia e Neuropsychologia, 4(1), 47-53. https://doi. org/10.1590/S1980-57642010DN40100008

Omranifard, V., Haghighizadeh, E., \& Akouchekian, S. (2018). Depression in Main Caregivers of Dementia Patients: Prevalence and Predictors. Advanced Biomedical Research, 7, 34. https://doi.org/10.4103/2277-9175.225924

Pakenham, K. I. (2001). Application of a stress and coping model to caregiving in multiple sclerosis. Psychology, Health and Medicine, 6(1), 13-27. https://doi. org $/ 10.1080 / 13548500125141$

Pakenham, Kenneth I, \& Bursnall, S. (2006). Relations between social support, appraisal and coping and both positive and negative outcomes for children of a parent with multiple sclerosis and comparisons with children of healthy parents. Clinical Rehabilitation, 20(8), 709-723. https:// doi.org/10.1191/0269215506cre976oa

Papastavrou, E., Andreou, P., Middleton, N., Papacostas, S., \& Georgiou, I. K. (2014).

Factors associated with quality of life among family members of patients with dementia in Cyprus. International Psychogeriatrics, 26(3), 443-452. https:// doi.org/10.1017/S104161021300224X

Pearlin, L. I., Mullan, J. T., Semple, S. J., \& Skaff, M. M. (1990). Caregiving and the stress process: An overview of concepts and their measures. Gerontologist, 30(5), 583-594. https://doi.org/10.1093/geront/30.5.583

Pinquart, M., \& Sörensen, S. (2004). Associations of caregiver stressors and uplifts with subjective well-being and depressive mood: A meta-analytic comparison. Aging and Mental Health, 8(5), 438-449. https://doi.org/10.1080 /13607860410001725036

Pinquart, M. \& Sörensen, S. (2007). Correlates of physical health of informal caregivers: A meta-analysis. In Journals of Gerontology - Series B Psychological Sciences and Social Sciences (Vol. 62, Issue 2). Gerontological Society of America. https://doi.org/10.1093/geronb/62.2.P126

Razani, J., Kakos, B., Orieta-Barbalace, C., Wong, J. T., Casas, R., Lu, P., Alessi, C., \& Josephson, K. (2007). Predicting caregiver burden from daily functional abilities of patients with mild dementia. Journal of the American Geriatrics Society, 55(9), 1415-1420. https://doi.org/10.1111/j.1532-5415.2007.01307.x 
Ruiz-Robledillo, N., \& Moya-Albiol, L. (2013). Self-reported health and cortisol awakening response in parents of people with asperger syndrome: The role of trait anger and anxiety, coping and burden. Psychology and Health, 28(11), 1246-1264. https://doi.org/10.1080/08870446.2013.800517

Sander, A. M., High, W. M., Hannay, H. J., \& Sherer, M. (1997). Predictors of psychological health in caregivers of patients with closed head injury. Brain Injury, 11(4), 235-250. https://doi.org/10.1080/026990597123548

Sandoval, F., Tamiya, N., Lloyd-Sherlock, P., \& Noguchi, H. (2019). The relationship between perceived social support and depressive symptoms in informal caregivers of community-dwelling older persons in Chile. Psychogeriatrics, 19(6), 547-556. https://doi.org/10.1111/psyg.12438

Santos, R. L., de Sousa, M. F. B., Simões-Neto, J. P., Nogueira, M. L., Belfort, T. T., Torres, B., da Rosa, R. D. L., Laks, J., \& Dourado, M. C. N. (2014). Qualidade de vida de cuidadores na demência leve e moderada. Arquivos de NeuroPsiquiatria, 72(12), 931-937. https://doi.org/10.1590/0004-282X20140155

Schulz, R, \& Williamson, G. M. (1991). A 2-year longitudinal study of depression among Alzheimer's caregivers. Psychology and Aging, 6(4), 569-578. https:// doi.org/10.1037//0882-7974.6.4.569

Schulz, Richard, \& Martire, L. M. (2004). Family Caregiving of Persons with Dementia: Prevalence, Health Effects, and Support Strategies. In American Journal of Geriatric Psychiatry (Vol. 12, Issue 3, pp. 240-249). Elsevier B.V. https://doi.org/10.1097/00019442-200405000-00002

Srivastava, G., Tripathi, R. K., Tiwari, S. C., Singh, B., \& Tripathi, S. M. (2016). Caregiver burden and quality of life of key caregivers of patients with dementia. Indian Journal of Psychological Medicine, 38(2), 133-136. https:// doi.org/10.4103/0253-7176.178779

Takai, M., Takahashi, M., Iwamitsu, Y., Oishi, S., \& Miyaoka, H. (2011). Subjective experiences of family caregivers of patients with dementia as predictive factors of quality of life. Psychogeriatrics, 11(2), 98-104. https://doi. org/10.1111/j.1479-8301.2011.00354.x

Teri, L. (1997). Behavior and caregiver burden: Behavioral problems in patients with Alzheimer disease and its association with caregiver distress. Alzheimer Disease and Associated Disorders, 11

Vaitheswaran, S., Lakshminarayanan, M., Ramanujam, V., Sargunan, S., \& Venkatesan, S. (2020). Experiences and needs of caregivers of persons with dementia in India during the COVID-19 pandemic-a qualitative study. American Journal of Geriatric Psychiatry. https://doi.org/10.1016/j. jagp.2020.06.026 
Van der Lee, J., Bakker, T. J. E. M., Duivenvoorden, H. J., \& Dröes, R. M. (2014). Multivariate models of subjective caregiver burden in dementia: A systematic review. In Ageing Research Reviews (Vol. 15, Issue 1, pp. 76-93). Elsevier Ireland Ltd. https://doi.org/10.1016/j.arr.2014.03.003

Veenstra, A., Ruth Mark, dr, \& Jütten, L. (2018).Social support and carers of people with dementia-the amount and quality of social support in noncaregivers versus caregivers of dementia. Unpublished bachelor thesis

Wackerbarth, S. B., \& Johnson, M. M. S. (2002). Essential information and support needs of family caregivers. Patient Education and Counseling, 47(2), 95-100. https://doi.org/10.1016/S0738-3991(01)00194-X

White, N. E., Richter, J. M., \& Fry, C. (1992). Coping, social support and adaptation to chronic illness. Western Journal of Nursing Research, 14(2), 211-224. https://doi.org/10.1177/019394599201400208

World Health Organisation. (2017). Global action plan on the public health response to dementia 2017 - 2025. In Geneva: World Health Organization. http://www.who.int/mental_health/neurology/dementia/action plan_2017_2 025/en/

Yates, M., Tennstedt S, \& Chang BH. (2009). Contributors to and mediators of psychological well-being for informal caregivers. The Journal of Gerontology. Series B, Psychological Sciences and Social Sciences, 54(2), 1222. https://doi.org/10.1111/j.1365-2648.2007.04494.x

Zanetti, O., Frisoni, G. B., Bianchetti, A., Tamanza, G., Cigoli, V., \& Trabucchi, M. (1998). Depressive symptoms of Alzheimer caregivers are mainly due to personal rather than patient factors. International Journal of Geriatric Psychiatry, 13(6), 358-367. https://doi.org/10.1002/(SICI)10991166(199806)13:6<358::AID-GPS772>3.0.CO;2-J

Zarit, S. H., Reever, K. E., \& Bach-Peterson, J. (1980). Relatives of the impaired elderly: Correlates of feelings of burden. Gerontologist, 20(6), 649-655. https://doi.org/10.1093/geront/20.6.649

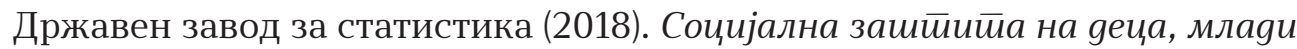
и возрасни лица. http://www.stat.gov.mk/PrikaziPoslednaPublikacija. aspx?id=22

Новотни, Г. (2019). Идентификација и евалуација на ризик и предикторни фактори за развој на Алцхајмерова болест. Необјавен докторски труд. 


\title{
PSYCHOLOGICAL BURDEN, DEPRESSION, SOCIAL SUPPORT AND COPING AS PREDICTORS OF QUALITY OF LIFE IN INFORMAL DEMENTIA CAREGIVERS
}

Marija Taneska

\begin{abstract}
The aim of this study is to investigate whether psychological burden, depression, social support, and coping styles of informal dementia caregivers can predict their quality of life. An international sample of 106 participants, of which 30 were from North Macedonia, was used. The variables were measured using the Dementia Carers Quality of Life Questionnaire (C-DEMQOL), PHQ-9, Zarit Burden Interview, the 11-item Perceived Support Scale and the Brief Approach/Avoidance Questionnaire. Self-report scales on the cognitive status and behavior of the person with dementia were also included. The study was conducted online. The results from the hierarchical regression analysis show that higher psychological burden and depression as opposed to lower social support predict worse quality of life in informal dementia caregivers. These findings emphasize the need of providing holistic systematic support to informal dementia caregivers in order to reduce the factors that compromise their quality of life.
\end{abstract}

Keywords: quality of life, informal dementia caregivers, psychological burden, depression, social support 